\title{
PERBANDINGAN REPRESENTASI ETNIS UIGHUR DI MEDIA BERITA CHINA DAILY DAN BBC
}

Comparison of Uighur's Ethnic Representation in China Daily and BBC News Media

\author{
Sun Wanting1 dan Kukuh Yudha Karnanta ${ }^{2}$ \\ Magister Kajian Sastra dan Budaya, Fakultas Ilmu Budaya, \\ Universitas Airlangga \\ 1anasun1211@gmail.com \\ 2ky_karnanta@yahoo.co.id
}

\begin{abstract}
Abstrak: Penelitian yang berjudul "Perbandingan representasi etnis Uighur di Media Berita China Daily dan BBC" ini dilakukan oleh peneliti untuk melihat citra etnis Uighur yang direpresentasikan oleh China Daily dan BBC. Metode penelitian ini menggunakan metode kualitatif dengan memanfaatkan pendekatan analisis wacana kritis model Teun A. Van Dijk terhadap analisis wacana media, yaitu melalui teks, kognisi sosial, dan konteks sosial dalam membongkar makna di balik perbedaan representasi teks berita terkait isu etnis Uighur oleh kedua media tersebut. Hasil penelitian ini menunjukkan bahwa media berita online China Daily cenderung memberitakan etnis Uighur dalam perspektif eksotisme. Sementara itu, media berita online BBC memberitakan etnis tersebut secara lebih problematik. Perbedaan ini terjadi dikarenakan adanya pengaruh kognisi sosial dan konteks sosial para wartawan, seperti China Daily yang berada di bawah pengawasan Partai Komunis China dan BBC yang telah dipengaruhi oleh lingkungan sosialnya (sikap kritik).
\end{abstract}

Kata-kata Kunci: Representasi, etnis Uighur, AWK van Dijk, China Daily, BBC

\begin{abstract}
The research entitled "Comparison Of Uighur's Ethnic Representation In China Daily And BBC News Media" was carried out by researchers to see the image of Uighur ethnicity represented by China Daily and BBC. This research uses qualitative method with approach of Critical Discourse Analysis Teun A. Van Dijk. Van Dijk's theory has three main dimensions, namely, texts, social cognitions, and social contexts that will be used to unravel the meaning behind different text-related representations of Uighur ethnic issues by both media. The results of this study indicate that the online news media China Daily tends to preach ethnic Uighurs in the perspective of exoticism. Meanwhile, the BBC's online news media reported the ethnic more problematically. This difference occurs because of the influence of social cognition and the social context of journalists, such as the China Daily under the supervision of the Chinese Communist Party and the $B B C$ which has been influenced by its social environment (criticism).
\end{abstract}

Keywords: Representation, Uighur ethnic, CDA van Dijk, China Daily, BBC

\section{PENDAHULUAN}

China merupakan salah satu Negara komunis yang menggunakan sistem satu- partai dan memegang teguh ateisme. Hal ini sesuai dengan fakta yang terjadi, yaitu mayoritas penduduk China berasal dari 
etnis Han, etnis yang tidak mengenal agama dan telah diakui oleh seluruh dunia. CIna juga merupakan salah satu negara yang terdapat $59 \%$ penduduknya mengaku tidak beragama dan sisanya sekitar delapan hingga 14\% mengaku beragama ${ }^{1}$.

Penduduk CIna mayoritas berasal dari etnis Han dan minoritas terdapat etnis Uighur, salah satu etnis minoritas resmi yang penduduknya beragama Islam. Etnis Uighur terletak di bagian paling ujung Barat China, Xinjiang. Awal sejarahnya, Etnis Uighur ini dikenal sebagai etnis keturunan Turki dan berbahasa Uihur, yaitu termasuk dari variasi bahasa Turki yang menggunakan aksara Arab (Bovingdon:2010). Sebagai salah satu kelompok minoritas dan beragama Islam di China, keberadaan etnis Uighur ini tentunya sangat menarik untuk diteliti kaitannya dengan hubungan interaksi antar etnis Han dan etnis Uighur dalam kehidupan sehari-hari. Berbagai dugaan terhadap potensi terjadinya konflik, pertanyaan hubungan praktik sosial, dan sebagainya yang telah terjadi di antara kedua etnis tersebut, sangat menarik perhatian seluruh masyarakat dunia.

Seiring dengan perkembangan zaman, hadirnya teknologi informasi saat ini menyebabkan berita tentang kehidupan etnis Uighur ini sering muncul di berbagai media massa dalam negeri ataupun luar negeri, khususnya Eropa. Fungsi media massa yang berbasis internet membuat seluruh kegiatan manusia semakin mudah untuk diketahui, direproduksi, dan disebarluaskan (Shuobo Yang: 2001). Pada zaman ini, media berita yang digunakan sebagaialat reproduksi informasi harus dipahami fungsinya dengan baik dan benar. Hal ini dikarenakan, media berita tidak hanya digunakan untuk menginformasikan fakta yang 'sesungguhnya' namun dapat

\footnotetext{
${ }^{1}$ Zuckerman, Phil. "atheism :Cintemporary Rates and Patterns', The Cambridege Companion to Atheism, ed.
}

dimanfaatkan oleh kalangan tertentu dalam mempengaruhi pembentukan opini masyarakat sesuai keinginannya, di antaranya: pengaruh ideologi, nilai-nilai sosial, gaya hidup, sistem politik, dan sebagainya. Adanya pengaruh yang diberikan oleh seluruh media komunikasi massa kepada masyarakat ini tentunya tidak secara langsung dapat disadari.

Lembaga-lembaga media komunikasi massa, khususnya media berita dapat mengontrol atau membatasi pengaruh ideologi masyarakat melalui produksi dan penyebaran informasi (Kan Kai: 2013), artinya, media berita dapat menggiring pemahaman ideologi seluruh masyarakat terhadap posisi atau keberadaan etnis Uighur di China, seperti pada contoh konkret terjadinya peristiwa atau konflik antara etnis Uighur dan etnis Han di dalam pemberitaan sebuah media berita terkait reperesentasi praktik sosial berikut.

Kunming Attack yang terjadi pada tanggal 01 Maret 2014. Kasus yang menceritakan tentang peristiwa sekelompok penjahat membawa senjata tajam, kemudian menyerang penumpang di Stasiun Kereta Kunming, Yunnan, Tiongkok. Kantor Berita Xinhua dan pemerintah Kunming mengatakan bahwa serangan tersebut dilakukan oleh teroris separatis Xinjiang dan media berita Time danThe New York Times pun juga melaporkan bahwa anggota komunitas Muslim Uighur Xinjiang lah yang terlibat dalam serangan tersebut. Peristiwa ini diduga sebagai bentuk 'kemerdekaan' yang dilakukan oleh para teroris etnis Uighur. Secara tidak langsung, terjadinya peristiwa ini termasuk sebagai konflik yang mengangkat isu SARA antara etnis Han dan etnis Uighur.

Contoh problematik di atas, tentunya tidak hanya menarik perhatian masyarakat China, tetapi juga masyarakat dunia namun

By Micheal Martin, Cambridge UniverisityPress : Cambridge, UK (2005) 
hasil representasi pemberitaan konflik tersebut, antara media berita China dan Luar sangatlah berbeda. Hal ini dikarenakan, media berita China terdapat campur tangan dari Partai Komunis China dan pemerintah China yang secara efektif dapat melakukan penyaringan berbagai informasi, dengan cara memberi batasan lembaga media, mencegah penyebaran berbagai teori heterogenitas, dan melakukan orientasi opini publik. Salah satu media berita yang sangat popular dan memiliki pengaruh terbesar bagi masyarakat China adalah media berita China Daily.

Media berita online China Daily menarik pembaca high-end dari berbagai bidang dengan rata-rata sirkulasi harian sebanyak 300.000 eksemplar ${ }^{2}$, media berita China yang mengikuti perkembangan zaman dan, memiliki taraf Internasional (secara online) meskipun di control oleh pemerintah China dalam hal penyebarannya. Media berita online China Daily inilah yang digunakan peneliti sebagai objek penelitian yang berasal dari dalam negeri (China) dan untuk media berita dari luar negeri, peneliti menggunakan British Broadcasting Corporation. Media berita online BBC dipilih karena menekankan status publiknya yang didanai oleh warga Inggris, dioperasikan secara mandiri, dan menyediakan berita-berita seputar Internasional di Internet. Tidak hanya itu, BBC juga merupakan salah satu media berita online yang telah dipengaruhi oleh sejarah lama, yaitu dimulai pada saat Inggris menjajah India, Inggris tidak hanya melakukan penjajahan di India, tetapi juga mengembangkan bisnisnya di ujung Barat China, Xinjiang (secara geografis berdekatan dengan India) sehingga pendiri

${ }^{2}$ http://www.chinadaily.com.cn/cd/200706/12/content 892204.htm diakses pada tanggal 21, Juli, 2018. Pukul 9:57 WIB. Profil China Daily.

${ }^{3}$ The National Literacy Trust adalah lembaga amal independen (terdaftar no. 1116260 di Inggris dan media berita online $\mathrm{BBC}$ ini secara tidak langsung telah memiliki keterkaitan cerita terhadap China, khususnya etnis Uighur.

Peneliti dalam hal ini memilih media berita online sebagai objek penelitian karena mudah dijangkau, meskipun platform media berita online mempunyai kelemahan dari sudut informasi kesementaraan, melalui platform media berita online kita dapat lebih mudah mencari informasi yang dulu dibandingkan dengan media berita cetak dan menurut survei dari National Literacy Trust ${ }^{3}$, 52\% penduduk dunia lebih suka membaca di layar, lebih cenderung membaca di perangkat elektronik daripada membaca materi berbasis kertas. Peneliti lembaga Nation Literacy Trust juga menemukan bahwa 39\% anak muda membaca setiap hari di komputer dan layar, dibandingkan dengan 28\% yang membaca setiap hari dengan menggunakan bahan cetak.

Alasan lain dari kedua media berita online tersebut yang cukup populer, media berita online China Daily yang populer di China dan media berita online $\mathrm{BBC}$ yang populer diseluruh dunia, terdapat pula perbedaan representasi berita yang menonjol, baik dalam judul ataupun isi berita pada isu yang sama terhadap etnis Uighur. Perbedaan representasi berita dapat ditunjukkan melalui judul berita seperti berikut: judul berita yang dituliskan oleh media berita online China Daily dan BBC, yaitu dengan judul "China bans Xinjiang officials from observing Ramadan fast ${ }^{4}$ "(China melarang jabatan Xinjang berpuasa pada bulan Ramadan) dan media berita online China Daily denganjudul "Rumors about Ramadan in
Wales dan tidak terdaftar. SCO42944 di Skotlandia) yang berbasis di London, Inggris.

${ }^{4}$ http://www.bbc.com/news/world-asia-china28123267diakses pada hari Selasa, 5 Juni 2018, pukul 9:29 WIB. 
Xinjiang are false $\boldsymbol{5}^{\text {") (berita tentang }}$ Ramadan di China tidak benar).

Berdasarkan problematik dalam pemberitaan representasi etnis Uighur antara kedua media berita online tersebut, peneliti menganalisis wacana di dalam media dengan memanfaatkan paradigma kritis melalui analisis wacana kritis van Dijk. Bagi van Dijk kognisi social dianggap paling utama dalam teori analisis wacana kritis karena berkaitan dengan kepentingan ideologi, politik, ekonomi, dan sebagainya yang dianggap sangat penting dalam membentuk dan mempengaruhi kognisi seseorang. Van Dijk membagi teorinya ke dalam tiga dimensi, yaitu teks, kognisi sosial, dan konteks sosial. Ketiga dimensi ini dimanfaatkan untuk mencari makna dibalik pemberitaan representasi etnis Uighur dalam media berita online China Daily dan media berita online BBC melalui judul penelitian, yaitu "Perbedaan Representasi Etnis Uighur dalam Media Berita online China Daily dan BBC".

\section{Landasan Teori}

Pada penelitian ini akan menggunakan teori analisis wacana kritis Van Dijk. AWK model Van Dijk membagi teorinya ke dalam tiga konsep analisis, yaitu 1).teks; 2).kognisi sosial; dan 3). Konteks sosial (Van Dijk, 2006:159). Ketiga konsep ini dalam proses pembangunan akan saling bergantung dan saling berpengaruh. Konsep teks terkait dengan strategi wacana pembuat yang berhubung dengan kognisinya; kognisi pembuat bekerja dalam proses memproduksi teks; konteks sosial sebagai aspek yang berkembang di dalam masyarakat akan mempengaruhi proses pemberitaan (van Dijk: 1991). Berikut ini adalah model analisis kritis van Dijk:

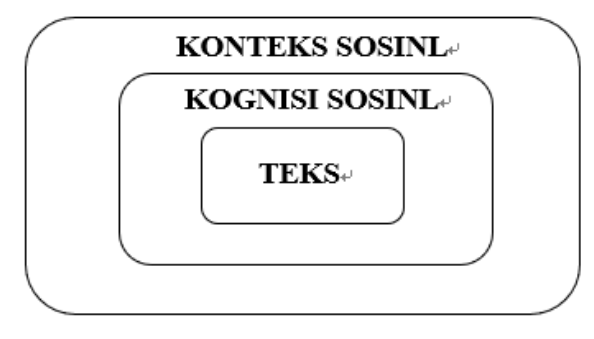

\section{Gambar 1. Model AWK van Dijk}

Analisis AWK Van Dijik yang pertama adalah teks (Van Dijk, 1991:2).Van Dijk membagi stuktur tes menjadi 3 bagian:

Pertama, struktur makro atau disebut juga dengan tematik. Secara harfiah, elemen tematik akan mengamati sebuah topik atau tema, dengan kata lain sturuktur makro ini bertujuan untuk melihat makna global/umum yang disampaikan oleh redatur/redaksi. Analisis stuktur makro dilakukan dengan memahami topik/tema kerena dari topik dapat diketahui gagasan sentral si pembuat naskah (van Dijk :1985).

Kedua, superstruktur atau juga disebut dengan skematik/alur. Kerangka teks telah didesain melalui skema atau alur. Susunan bagian-bagian sebuah teks dari awal hingga akhir telah diikuti dengan kerangka yang sudah ditentukan oleh penulis atau pembuat teks. Skema secara umum dibagi ke dalam dua kategori, yaitu pertama adalah summary, biasanya ditandai dengan judul dan teras berita, dan kedua adalah isi berita secara keseluruhan. Pada isi berita juga dibagi menjadi dua subkategori, yakni situasi sebagai porses atau jalannya pertisiwa dan komentar yang ditampilkan dalam teks.

Ketiga, sturktur mikro, struktur wacana ini terdiri atas:

Retoris itu terlibat dengan 1) metafora dan ekspresi untuk menyampaikan

${ }^{5}$ http://www.chinadaily.com.cn/china/60thxjannivesar y/2015-07/17/content 21315073.htm diaskses pada hari Sabtu, 30 Juni 2018, pukul 13.28 WIB. 
maksud secara narasi, eksposisi, agrumentasi, persuasi dan deskripsi. 2) elemen grafis, juga termasuk bidang stailistik, dalam menciptakan sebuah teks, pembuat menggunakan teknik pengeditan format, misalnya pemakaian gambar, chart, tebel, huruf tebal, huruf miring, garis bawah, huruf dengan ukuran lebih besar untuk menonjol material dan menarik perhatian dari pembaca.

Stailistik, analisis stailistik sama dengan analisis tentang pilihan kata yang digunakan oleh pembuat. Dengan kata lain, Stailistik itu terdiri dari leksikon, Analisis leksikon itu untuk mencari makna dan arti yang dibelakang kata yang dipakai untuk menulis teks. Oleh kerena itu leksikon terlibat dengan kognisi dan konteks ideologsi sosial. Sehingga dalam penentuan sikap ideologi, diksi/kata yang dipakai oleh redaktur dapat diteliti. Bagi sebuah hal yang sama, jika dipilih dengan diksi/kata yang berbeda, pemahaman pembaca tenteng hal tersebut ini juga berbeda.

Stailistik itu terlibat dengan 1) gaya penelitian, misalnya, narasi, eksposisi, agrumentasi, persuasi dan deskripsi. 2) elemen grafis, juga termasuk bidang stailistik, dalam menciptakan sebuah teks, pembuat menggunakan teknik pengeditan format, misalnya pemakaian gambar, chart, tebel, huruf tebal, huruf miring, garis bawah, huruf dengan ukuran lebih besar untuk menonjol material dan menarik perhatian dari pembaca.

Sintaksis (Analisis Kalimat), Sintaksis memainkan peran penting dalam mengimplikasikan ideologi, melalui sintaksis yang dipakai, rekadsi dapat mengarahkan pembaca terhadap sesuatu peristiwa ke arah positif atau negatif. Kemudian tingkatan sintaksis sebagai berikut ini:

- Koherensi: dua kata, kalimat yang secara independen setelah dirangkai dapat tersambung dan tempak koheren. Sedangkan koherensi itu terdiri dari 3 eleman sebagai berikut ini: a) Koherensi sebab-akibat; b) Koherensi penjelas; c) Koherensi pembeda.

- Peningkaran: dengan cara implisit, redaksi menggambarkan gagasanya seolah-olah menyetujui sesuatu, tapi padahal tidak setuju.

- Bentuk Kalimat: Sebuah kalimat harus diatur sesuai dengan pola tertentu, pola ini disebut bentuk kalimat. Bentuk kalimat juga diikuti dengan bentuk deduktif atau induktif. Kata Ganti: Penggunaan kata ganti sering melibatkan anafora, di mana arti kata ganti tergantung pada elemen referensial lainnya.

- Semantik (makna lokal): objek penelitian semantik bisa berupa katakata, frasa, kalimat, teks, dan tingkat unit bahasa yang berbeda. Analisis semantik ini dibutuhkan banyak pengetahuan linguistik kerena fokusnya untuk mencari makna dengan mulai dari semantik (Haryatmoko, 2016:85). Semantik biasanya membantu membentuk topik dan makna yang terkesan penerima. Analisis semantik ini meliputi latar, detail, maksud, pra-anggapan.

- Latar, penjelasan latar dalam proses pembuatan teks sangat berefek pada kognisi pembaca. Dalam taraf tertentu, latar juga dapat mencerminkan kognisi dan ideologi peneliti. Seorang redaksi ketika mengeluarkan sebuah pendapat, biasanya latar belakang akan dijelalskan untuk mengemukakan apa yang terjadi.

- Detail, pembuat teks menulis teks dengan mengnontrol jumlah informasi (Nurul, 2017:207). Secara rinci, informasi-informasi yang diberikan olehnya secara lengkap dan panjang, dengan lebih konkret, dengan pemilihan informasi yang disediakan oleh peneliti, terdapat 
menggambarkan citra yang mau disampaikan kepada pembaca.

- Maksud, citra yang dicipatkan oleh pembuat telah terkesan kepada pembaca. Melalui membaca, pembaca telah mengerti informasi yang diperolehnya. Teks itu terlihat eksplisit dan jelas. Fakta yang disajikan cukup gamblang.

- Pra-anggapan. Atau juga dapat disebut dengna antisipasi. Pada tulisan awal peneliti telah melakukan antisipasi berdasarkan basis rasional, sehingga pengumpulan informasi teks akan dijalankan ke arah yang dianggap mendukung pikiran peneliti. Dalam proses pembuatan teks, peneliti berusuah untuk membukti pandangnya dapat dipercaya.

Selain itu, Kognisi sosial dapat mempengaruhi seseorang dalam proses pembuatan gambaran tentang realitas. Sehingga menurut van Dijk (1985: 4), analisis teks juga harus diamati kognisi sosialnya. Proses kognisi sosial didasarkan pada pengalaman masa lalu dari kesadaran dan analisis petunjuk yang relevan. Biasanya kognisi sosial itu juga dianggap spontan. (Haryatmono, 2016:86). Kogisi sosial seorang wartawan dibangun melalui pemrosesan informasi, penalaran, klasifikasi, dan induksi,secara sederhana atau ringkas, teks sebagai upaya untuk mengungkap makna yang tersirat dari posisi pembuat teks dapat bersifat tidak netral. Dalam sebuah teks, perspektif si pembuat yang abstrak akan disampaikan ${ }^{6}$. Perilaku individu dapat mencerminkan kognisi sosial, individu dengan kognisi sosial yang berbeda, hasil keputusan juga akan berbagai (Guoliang : 2006).

Kognisi sosial dapat dibangun oleh informasi-informasi yang diperoleh penerima. Pembaca akan menganggap

\footnotetext{
6 Alex Sobur, analisis Teks Media Suatu Pengatur untuk Analisis Wacana, Semiotik, dan Analisis Framing.
}

informasi mereka dapatkan dari media pers sebagai komponen untuk membangun kognisi sosial mereka diri sendiri (Ron Scollon : 1998). Menurut Van Dijk, wacana itu memiliki pengaruh dari "kognisi sosial" atau kesadaran mental seseorang dilingkungan sekitarnya (van Dijk 2009 dalam Haryatmoko, 2016: 80).

Van Dijk tidak hanya meneliti wacana teks yang dikonstruksi saja, tetapi juga menganalisa wacana yang berkembang di masyarakat. Dimensi analisis konteks sosial van Dijk (van Dijk, 1998:119) adalah praktik kekuasan dan akses yang akan dilihat. Konteks sosial adalah penjumlahan dari fenomena kehidupan spiritual sosial, yaitu jumlah dari ide, sudut pandang, dan konsep yang secara langsung terkait dengan aspek ekonomi dan politik dari masyarakat tertentu, termasuk ide politik dan hukum, moralitas, sastra dan seni, agama, filsafat, dan ilmu sosial lainnya7. Dengan kata lain, lingkungan orang yang membesarkan dapat memberi pengaruhan secara langsung dan tidak langsung. Peneliti dalam hal ini melakukan wawancara langsung dengan pihak-pihak redaksi.

Konteks sosial dapat membantu menganalisis maksud atau arti tersembunyi dibalik suatu wacana ideologi yang ingin disampaikan oleh pembuat teks, suatu wacana yang dilatarbelakangi konteks sosial tentunya memiliki beberapa kepentingan, misalnya kepentingan berupa ideologi, politik, ekonomi, dan sebagainya. Konteks sosial menangkut dengan gagasan, keyakinan, sistem kepercayaan, masalah politik. Representasi dan interpretasi sosial akan digambarkan dengan wacana (Van Dijik , 2009 : 11). Dua elemen yang penting dalam analisis konteks sosial yaitu, praktik kekuasan dan akses.

\footnotetext{
${ }^{7}$ https://baike.baidu.com/item/社会意识形

/10702993?fr=aladdin diaskes pada tanggal 20 Juni 2018.
} 


\section{METODE}

Penelitian ini menggunakan metode penelitian kualitatif. Penelitian yang berfokus pada analisis fenomena sosial secara mendalam. Penelitian kualitatif bertujuan untuk menjelaskan suatu fenomena tertentu secara mendalam dengan melakukan pengumpulan data secara lengkap (Kriyantono: 2006). Metode kualitatif ini dapat mengamati suatu fenomena secara mendalam dan menyeluruh (Moleong, 2011:4). Metode kualitatif dipilih oleh peneliti sebagai metode penelitian karena ingin menggambarkan suatu masalah secara deskriptif dalam proses penelitian. Pada kajian ini, peneliti melihat bahwa ada fenomena yang berbeda muncul dalam menginterpretasi dan mereperesentasi etnis Uighur yang dilakukan oleh media berita online China Daily dan BBC.

Oleh karena itu, melalui penelitian ini penulis akan mendeskripsikan bagaimana representasi etnis Uighur yang telah dibangun oleh media berita online China Daily dan BBC, dan menjawab pertanyaan "mengapa" peristiwa dalam perbedaan represntasi di antara kedua media berita online tersebut dapat terjadi. Peneliti akan menjelaskan metode penelitian ini ke dalam tiga bagian, yaitu pemilihan objek, pengumpulan data (wawancara langsung), dan analisis data.

\section{HASIL DAN PEMBAHASAN \\ Analisis teks:}

\section{Reperentasi Entis Uighur di China Daily dalam Berita "Rumors about Ramadan in Xinjiang are false"}

Pada berita ini, makna keseluruhan yang ingin disampaikan oleh media berita online China Daily, yaitu penjelasan terkait (laporan media asing) pada bulan Ramadhan di Xinjiang tidak benar. Secara umum, berita ini dibagi dan didukung dengan sub-topik masing-masing. Berikut adalah kutipan hasil laporan wawancara langsung yang didapat seperti ini:
"I have the freedom of religious belief in Xinjiang. I also see that Xinjiang Muslims are praying and fasting during Ramadan without any barriers." said Ulkar Ozturk, a Turkish Xinjiang. ("Saya memiliki kebebasan agama di Xinjiang. Saya juga melihat bahwa Muslim Xinjiang sedang berdoa dan berpuasa selama Ramadhan tanpa hambatan apapun," kata Ulkar Ozturk, seorang Xinjiang Turki.)

Berdasarkan kutipan diatas, tema utama telah dibuat secara jelas agar pembaca dapat memperoleh informasi bahwa di Xinjiang ketika bulan Ramadhan tiba, seluruh orang-orang yang beragama Islam diizinkan untuk melakukan ibadah puasa. Suasana damai selama bulan Ramadhan telah direpresentasikan dengan baik oleh media berita online China Daily.

Analisis superstruktur selalu berkaitan dengan pendahuluan, isi, penutup, dan simpulan dalam sebuah wacana dari keseluruhan paragraf teks berita. Topik atau tema disampaikan melalui kalimat untuk mendukung sikap "ketidakbenaran" terkait larangan puasa pada bulan Ramadan.Redaksi media berita online China Daily mengeluarkan beberapa bukti yang dapat diklasifikasikan dari awal hingga akhir teks sebagai berikut ini:

1) Awal kalimat berita, yaitu paragraf pertama atau bisa disebut juga sebagai teras berita (lead), redaksi secara terus terang mengatakan bahwa kabar mengenai muslim Xinjiang pada Ramadan itu salah. Penulis dalam teksnya memberikan kesimpulan langsung di awal artikel ini, kemudian pada paragraf selanjutnya penulis memberikan contoh konkret untuk mendukung summary yang telah diberikan pada paragraf pertama. 
2) Penulis menggunakan "ungkapan" dari pedagang Turki dan returned overseas Chinese, sebagai ornamen atau bumbu dalam berita ini untuk menyangkal rumor larangan puasa pada bulan Ramadan oleh umat Muslim di Xinjiang.

"The rumors and

demonstrations are all by the illintentioned ones who want to use the Uyghur people for their own conspiracy," he said ("rumor dan demonstrasi semua oleh orang-orang yang bermaksud jahat yang ingin menggunakan orang-orang Uyghur untuk konspirasi mereka sendiri," katanya)

3) Pada paragraf akhir, penulis menuliskan bahwa kita harus menjelaskan kebijakan agama dan etnis di China agar rumor tidak akan disebarkan lagi.

Setelah membaca keseluruhan paragraf dalam berita ini secara satu demi satu, bentuk susunan paragraf sangat menentukan kualitas wacana, dimana setiap paragraf saling mendukung dan akhirnya membuat berita ini dilhat utuh dan bermakna, yaitu di Xinjiang puasa pada Ramadan itu normal.

\section{Reperentasi Etnis Uighur di BBC dalam Berita "China bans Xinjiang officials from observing Ramadan Fast"}

Berdasarkan dari struktur makro berita ini, secara makna global menjelaskan bahwa pemerintah China melarang pejabat Xinjiang China untuk melakukan puasa pada bulan Ramadhan. Tema terhadap pemerintah China dibentuk secara negatif dalam mempengaruhi pembaca.

Skema berita ini juga mengandung satu sub-judul, dengan berita subjudul yang di cetak tebal "increasing tension". Bagian subjudul ini telah diberikan contoh sebagai bentuk penegasan dalam membuktikan bahwa di China ada larangan puasa untuk umat Muslim. Hal ini dikarenakan apabila ada kebebasan terhadap budaya dan agama bagi etnis Uighur yang dilakukan oleh pemerintah China akan memicu terjadinya kerusuhan di kawasan Xinjiang dan kemungkinan dapat tmenyebar di seluruh wilayah China.

"We remind everyone that they are not permitted to observe a Ramadan fast," ("Kami mengingatkan semua orang bahwa mereka tidak diizinkan untuk mengamati puasa Ramadhan,")

Berdasarkan kutipan di atas, dengan menggunakan kata "we" dan "they", penulis ingin menunjukan bahwa di China dibedakan dengan kata "we" dan "they" kepada kelompok yang beragama dan yang tidak beragama. Adanya pembeda ini menunjukkan bahwa terdapat pemisahan antaretnis, yaitu etnis Uighur dengan etnis lain yang berada di China.

Pada bagian ini, pilihan kata akan diperhatikan secara teliti. Dalam artikel berita ini, penulis fokus pada penyampaianlarangan puasa yang telah dimaknai dan dilebeli dengan diksi tertentu sesuai kepentingannya. Kata-kata tertentu tersebut dapat dilihat sebagai berikut ini: “crackdown", "extremist Uighurs". Artikel berita yang disampaikan dengan menggunakan pemilihan kata sifat ini, menunjukkan bahwa redaksi ingin mengarahkan dan mengkonstruksikan citra etnis Uighur ke arah negatif, yaitu tidak ada hak dan kebebasan beragama terhadap etnis Uighur di China. Informasi yang ingin disampaikan oleh redaksi adalah kehidupan etnis Uighur di China yang kurang bahagia dan bebas.

Analisis retoris, penulis artikel berita ini menggunakan grafis yang dituliskan pada teras berita, dengan menuliskan teksnya secara langsung dan dicetak tebal. Maksud redaksi ini bertujuan untuk 
menonjolkan kondisi larangan puasa yang terjadi di China.

Secara rinci analisis teks berita dari China Daily etnis Uighur yang memiliki agama dikontrol secara ketat oleh pemerintahan China. Dimana media berita online China Daily yang cenderung memfokuskan berita pada penanganan efektif pemerintah China terhadap etnis Uighur dan menekankan pengenalan kebijakan-kebijakan yang mendukung etnis etnis minoritas ini, seperti menghormati keyakinan agama, membantu orang Uighur untuk berkembang secara harmonis, mempromosikan persatuan nasional, mempropaganda pemandangan yang eksotis di Xinjiang, secara aktif membangun citra yang sehat antara citra China dan citra etnis Uighur; akan tetapi, hal ini terjadi sebaliknya pada media berita online $\mathrm{BBC}$ yang memfokuskan berita pada penanganan tidak tepat, dimana mengkritik pemerintah China karena kebijakannya yang terlalu memberatkan orang Uighur, ketidakpuasan dengan Uighur, dan terkait hak kebebasan atau kehidupan etnis Uighur di China. Sehingga media berita ini cenderung lebih menciptakan citra negatif terkait "masalah China" bagi pembaca.

\section{Kognisi redaksi China Daily terhadap Reperentasi Etnis Uighur:}

Peneliti dalam membongkar artikel teks berita ini, telah melakukan wawancara dengan wartawan redaksi China Daily. Akan tetapi, pada awal pengumpulan data dan meminta ijin wawancara kepada wartawan China Daily, peneliti mengalami kesulitan. Pihak China Daily menolak wawancara secara terus menerus, sampai pada akhirnya peneliti dapat menghubungi salah seorang wartawan dari International Daily News yang bernama G.(nama anonim). Menurut G. (nama anonim) pihak China Daily menolak wawancara karena sebagai sebuah koran harian dan mewakili
Partai Komunis China, biasanya wartawan tidak akan membicarakan masalah yang dianggap sensitif ini, seperti pada persoalan etnis Uighur di Xinjiang dengan posisi istimewanya karena fungsi utama China Daily adalah untuk propaganda kebijakan Negara (2018).

Makna penolakan wawancara yang dilakukan oleh redaksi China Daily, yaitu adanya pengaruh yang kuat dari instansi China Daily, sebuah instansiyang juga telah dipengaruhi secara kuat oleh partai komunis. Partai komunis merupakan partai yang berkuasa di Republik Rakyat China sehingga berbagai aturan yang telah mereka tetapkan harus ditaati oleh seluruh masyarakatnya, termasuk instansi yang bergerak dalam bidang komunikasi massa. Artinya, tidak ada rasa kebebasan yang dimiliki oleh seluruh masyarakat dan berbagai instansi di China, baik kebebasan berekspresi, berpendapat, dan sebagainya apabila terdapat sebuah pelanggaran atau tidak menaati aturan-aturan yang telah ditetapkan pemerintah, maka akan mendapatkan hukuman, seperti misalnya dalam instansi yang bergerakdi bidang komunikasi massa akan terjadi pembungkaman jika pihak instansi telah melakukan sebuah pelanggaran.

\section{Kognisi redaksi BBC terhadap Reperentasi Etnis Uighur:}

Menurut John kebebasan berbicara di China masih sangat tertutup, meskipun hak manusia etnis minoritas dan kebebasan agama telah dibuat secara tertulis oleh pemerintah China namun pada kenyataannya itu semua berbeda. Peristiwa tersebut menurut oleh John Sudworth karena telah dipengaruhi oleh kondisi lingkungan China itu sendiri. Sebagai seorang wartawan BBC pun, John sudworth juga memiliki rasa tanggung jawab dalam menggali konotasi-konotasi yang ada secara lebih dalam.

Berdasarkan pengalaman sebagai wartawan BBC di China, John selalu 
mengingat bahwa tugas wartawan yaitu menyampaikan berita dengan otoritas, mengajukan pertanyaan yang tepat dalam sebuah wawancara, dan dapat dengan cepat menyerap informasi yang ada di China. Seperti yang telah diuraikan dalam hasil kognisi sosial redaksi BBC yang telah dibangun tersebut, hal inilah yang menyebabkan kognisi redaksi BBC membuat citra etnis Uighur ke arah negatif karena realitasnya yang mereka lihat memang sangat kurang. Wilayah Xinjiang termasuk dalam wilayah miskin apabila dibandingkan dengan kota-kota maju yang ada di China sehingga Xinjiang membutuh perhatian pemerintah dalam perkembangannya. Akan tetapi, pemerintah China mengabaikan kewajibannya tersebut.

\section{Aspek Konteks Sosial dalam Pemberitaan China Daily terhadap Etnis Uighur}

Melalui analisis konteks sosial, bertujuan untuk membongkar bagaimana wacana tentang suatu objek dikonstruksi dan diproduksi di dalam masyarakat. Konteks sosial pada wacana representasi etnis Uighur di dalam media berita online China Daily. Keberadaan Etnis Uighur telah dicatat sejak berabad-abad silam. Etnis Uighur merupakan etnis keturunan Turki yang hidup di Asia Tengah, terutama di Xinjiang, China. Xinjiang sebagai daratan pedalaman Asia dan Eropa telah memiliki sejarah panjang dengan Dataran Tengah China ${ }^{8}$. Sejak zaman kuno, Xinjiang telah menjadi wilayah di mana banyak kelompok etnis hidup bersama dan berbagai umat agama saling hidup berdampingan. Sejak Dinasti Han Barat (206 SM-24 M), Xinjiang telah menjadi bagian integral dari negara multi-etnis terpadu China ${ }^{9}$. Selanjutnya penulis akan membahas historiografi etnis Uighur di

\footnotetext{
${ }^{8}$ Kantor Informasi Dewan Negara. 2003.
}

masa lalu hingga sekarang, khsusunya etnis Uighur pada zaman kekaisaran dan modern. Berdasarkan penjelasan sejarah di atas, menurut pemerintah China, Xinjiang telah menjadi wilayah China sejak zaman dulu sehingga masyarakat Xinjiang perlu melakukan tuntutan terhadap kebijakan-kebijakan yang diberikan oleh negara China.

Pemerintah China juga menganggap bahwa Xinjiang termasuk lingkup pimpinan negara komunis sehingga pemerintah China juga mempunyai kewajiban dalam membawa Xinjiang ke kehidupan yang makmur. China bermaksud untuk mewujudkan kehidupan yang selaras, dalam konteks sosial media berita sebagai alat propaganda di China wajib mendukung dan merepenstasikan etnis Uighur secara baik, seperti yang digambarkan oleh media berita online China Daily terkait persoalan etnis Uighur.

\section{Aspek Konteks Sosial dalam Pemberitaan China Daily terhadap Etnis Uighur}

Hubungan antara Inggris zaman modern dan Xinjiang adalah hasil dari perkembangan kapitalisme Inggris. Inggris adalah sebuah negara yang terletak di kepulauan Eropa, Xinjiang adalah sebuah provinsi di China, sebenarnya secara geografis tidak ada hubungan di antara keduanya, tetapi dengan keberhasilan revolusi industri Inggris dalam memperluas pasar bisnis, Inggris secara tidak langsung mulai berhubungan dengan Xinjiang (Jianying Xu: 2002). Berdasarkan perspektif historis di atas, kita dapat melihat hubungan antara Inggris dan Xinjiang dalam politik, ekonomi, agama, dan budaya. Pemahaman masyarakat Inggris dan pemerintah Inggris sendiri terhadap Xinjiang pada zaman modern tersebut juga akan mempengaruhi

${ }^{9}$ White $\quad 2006 . \quad$ Paper, http://politics. people.com.cn/GB/8198/58705/59794/4187169.html diaskes pada tanggal $1 \mathrm{Juli}, 2018$. 
pengenalan masyarakat Inggris yang sekarang.

\section{SIMPULAN}

Berdasarkan hasil analisis sebelumnya terkait wacana represntasi etnis Uighur dalam media berita online China Daily dan BBC, melalui dimensi teks, kognisi sosial, dan konteks sosial dapat disimpulkan bahwa China Daily lebih cenderung memberitakan etnis Uighur dalam perspektif eksotisme. Sementara itu, media berita online BBC memberitakan etnis tersebut secara lebih problematik. Hal ini dikarenakan, pemerintah China bersama China Daily ingin membangun kesejahteraan hidup bagi persatuan dan keutuhan bangsa China. Sedangkan hasil analisis dari pihak BBC, pembentukan teks berita dalam merepresentasikan etnis Uighur, BBC menciptakan citra Uighur dan pemerintaah China ke arah yang negatif. Hal ini dapat ditunjukan melalui tema, diksi, dan retoris yang digunakan oleh redaksi BBC.

Alasan adanya perbedaan reprentasi terhadap enits Uigur, setelah dilakukan analisis dari dimensi kognisi dan kontek sosialnya ialah media berita online China Daily yang lahir di China sehingga kognisi redaksi memiliki pengaruh dari konteks sosial China yang menakankan keharmonisan kelompok etnis. Sedangkan untuk media berita online BBC yang lahir di Inggris, kognisi redaksi tentunya telah bergabung dengan pengalaman dan pengetahuan yang telah dipengaruhi oleh konteks sosial Inggris, ideologi Inggris yang memperhatikan hak dan kebebasan manusia, khususnya antar kelompok etnis. Hal ini tidak lain karena adanya pengaruh dari beberapa faktor seperti latar belakang pengetahuan, geografis, sejarah, sosial, budaya, pengalaman, dan spek-aspek lain.

\section{DAFTAR PUSTAKA}

Bovingdon, Gardner. 2010. The Uyghurs Strangers in Their Own Land. New York: Columbia University Press.

Eriyanto, 2001. Analisis wacana: pengantar analisi steks media. Yogyakarta: LkiS Yogyakarta.

Guoliang, Yu. 2006. Psikologi Sosial. Beijing: Normal University Press.

Haryatmoko. 2016. Critical Discourse Analysis. Jakarta :Rajawali Pers.

Kriyantono, Rachmat. 2006. Teknik Praktis Riset Komunikasi. Jakarta: Prenada.

Ron, Scollon. 1998. Why habitus isn't enough for Critical Discourse Analysis. Georgetown University.

Shubo, Yang. 2001. Evolusi budaya konsumen kapitalis, peran media dan globalisasi. Berita dan Ilmu Komunikasi. 2001 (1): 36-43.

Van Dijk, Teun A. 1980. Macrosturctures: An Interdisciplinar Study of Global Strucutres In Discourse, Interaction, and Cognition. Lawrence Erlbaum Associates.

Van Dijk, Teun A. 1991. Social Cognition And Discourse. London : Sage Publications

Van Dijk, Teun A. 1997. Discourse as Social Interaction. London Sage Publications.

Van Dijk, Teun A. 1998. News as Discourse. Hillsdale. New Jersey: Lawrence Erlbaum Associates.

Van Dijk, Teun A.2006. Discourse, Context and Cognition. London: Thousand Oaks.

Van Dijk, Teun A. 2008. Discourse and Context: A Sociocognitive Approach. Cambridge: Cambridge University Press.

Van Dijk, Teun A. 2009. Society and Discourse : How Social Contexts Influence Text and Talk. Cambridge: Cambridge University Press.

\section{Web Online:}


http://www.chinadaily.com.cn/china/201 5-07/14/content_21271913.htm diakses pada tanggal 02 April 2018 http://www.bbc.com/news/world-asiachina-28123267 diakses pada hari Selasa, 05 Juni 2018, pukul09.29 WIB.

https://baike.baidu.com/item/社会意识 形态/10702993?fr=aladdin diaskes pada tanggal 20 Juni 2018, pukul 09.30 WIB.

http://www.mesi.shisu.edu.cn/0d/ce/c37 13a69070/page.htm diakses pada tanggal 10 Juni tahun 2017.

https://www.bbc.com/news/world-asiachina-28123267 diakses pada tanggal 02 April 2018.

https://www.chinadaily.com.cn/ethnic/2 009-09/21/content_8717461_7.htm diaskes pada tanggal 31 Maret 2018.

https://www.bbc.com/news/av/worldmiddle-east-40672258/egypt-suighurs-feardeportation-to-china diaskes pada tanggal 31 Maret 2018. https://www.bbc.com/news/world-asiachina-33440998 diakses pada tanggal 31 Maret 2018.

http://www.bbc.com/culture/story/2013 1215-how-china-portrays-itsminorities diaskes pada tanggal 31Maret 2018.

https://wenku.baidu.com/view/a9bfe929 31b765ce050814fb.html diakses pada tanggal 06 Juni 2018.

https://www.chinadaily.com.cn/static_c/ gyzgrbwz.html China Daily tentang kami, diaskes pada tanggal 04 Juni 2018.

http://www.chinadaily.com.cn/china/60t hxjannivesary/201508/17/content_ 21623188.htm diakses pada tangggal 02 April 2018.White Paper, 2006.

http://politics.people.com.cn/GB/8198/5 8705/59794/4187169.html diaskes pada tanggal 01 Juli 2018. http://www.bbc.com/news/world-asiachina-28123267 diakses pada tanggal 01 April 2018.

http://www.chinadaily.com.cn/china/60t hxjannivesary/201509/23/content_ 21963271_3.htm diakses pada tanggal 05 Juni 2018.

http://www.chinadaily.com.cn/china/60t hxjannivesary/201510/01/content_ 22138048.htm diakses pada tanggal 05 Juni 2018.

http://www.bbc.com/news/world-asiachina-33440998 diaskes pada tanggal 01 April 2018.

http://www.chinadaily.com.cn/china/60t hxjannivesary/201509/19/content_ 21926270.htm diakses pada tanggal 04 Juni 2018.

http://www.bbc.com/news/world-asiachina-33440998 di askes pada tanggal 01 April 2018.

http://www.chinadaily.com.cn/china/201 4npcandcppcc/201403/12/content 17340497.htm diakese pada tanggal 04 Juni 2018.

Li Xuliang : 2017, https://zhidao.baidu.com/question/ 72068164.html diaskes pada tanggal 03 Juni 2018. Mengenai jumlah faksi yang berada di China daratan.. 